\title{
Despite benefits, commercialization of transgenic horticultural crops lags
}

\author{
David Clark \\ Harry Klee \\ Abhaya Dandekar
}

The acreage of agronomic crops (soybean, cotton, corn and canola) developed using recombinant DNA technology has expanded dramatically since their introduction in 1996, while the commercialization of biotech horticultural crops (vegetables, fruits, nuts and ornamentals) has languished. This is not due to a lack of both current and potential traits that could be utilized in horticultural crops, as ongoing research is identifying a diverse array of applications. However, commercialization is stalled by market reluctance to accept biotech products, particularly in the absence of clear benefits to consumers. High regulatory costs and restricted access to intellectual property create additional hurdles for specialty crops. These challenges are causing the horticultural industry to forego a number of current benefits. New products with clear advantages for producers, marketers and consumers may be required before the potential of biotechnology can be realized.

\section{TT 2003, nearly 106 million acres of transgenic or genetically} engineered (GE) crops was planted in the United States, part of 167 million acres of such crops grown worldwide (James 2003). Despite the fact that the first commercialized transgenic food crop was the Flavr Savr tomato, four agronomic crops (corn, soy, cotton and canola) account for virtually all of the current acreage. Last year, only four horticultural crops developed using recombinant DNA technology were avail- able in the United States: papaya, sweet corn, squash and a carnation. Except for transgenic papaya, which accounts for approximately $50 \%$ of the Hawaiian crop (HASS 2001), the fraction of the total horticultural commodities represented by transgenic varieties is miniscule.

The absence of significant commercialization of transgenic varieties in horticulture is not due to lack of potential products or value (Dandekar and Gutterson 2000; see sidebar, page 94). The basic techniques of molecular biology have become routine, and considerable research is being conducted on horticultural crops. For example, herbicide resistance has been transferred into bentgrass and bluegrass to make weed control in municipal and highly managed turf environments such as golf courses more efficient. However, they have not been commercialized. Similarly, some horticultural crops, including lettuce and tomato, have been engineered with herbicide resistance and tested in field trials but remain un- commercialized. Disease resistance, particularly to viruses, can be developed using biotechnology, and potato and papaya cultivars engineered for virus resistance have been commercialized, but many potential applications are currently underutilized. Improving traits that directly benefit consumers, such as nutritional or aesthetic quality, is also technically feasible now in many horticultural crops, but only a few products have reached the market.

\section{Approved traits and technologies}

The major technologies that have been approved and widely adopted by the industry focus on input traits, or those affecting production of the crop rather than the qualities of the final product. Although most approved genes confer insect resistance and herbicide tolerance, a range of genetic traits has been approved by the U.S. regulatory system (table 1 ).

Insect resistance. Insect resistance has been engineered primarily by using

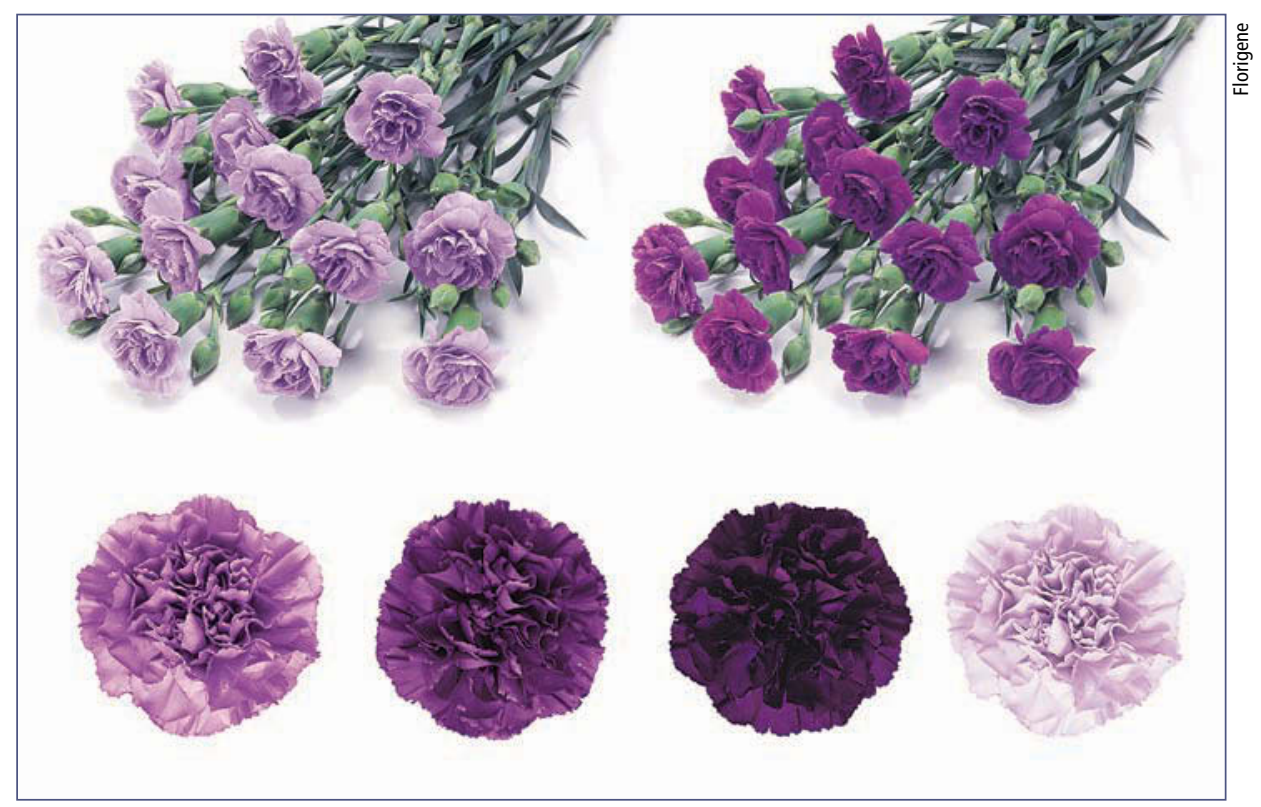

Florigene, of Melbourne, Australia, markets transgenic carnations engineered for blue-violet color under the variety name 'Moonshadow'. 
TABLE 1. Approved transgenic traits for U.S. crops

\begin{tabular}{|c|c|}
\hline Trait & Examples \\
\hline Herbicide tolerance & Bromoxynil, glufosinate, glyphosate, sulfonylurea \\
\hline Insect resistance & Bt kurstaki, Bt tenebrionis \\
\hline Virus resistance & $\begin{array}{l}\text { Papaya ringspot virus, cucumber mosaic virus, zucchini } \\
\text { yellow mosaic virus, watermelon mosaic virus, } \\
\text { potato leaf roll virus, potato virus } Y\end{array}$ \\
\hline Male sterility & Barnase/barstar \\
\hline Modified ripening & $\begin{array}{l}\text { ACC synthase, ACC deaminase, SAM hydrolase, } \\
\text { polygalacturonase }\end{array}$ \\
\hline Modified oils & High lauric, myristic, oleic acids \\
\hline
\end{tabular}

two classes of bacterial genes derived from Bacillus thuringiensis (Bt) ssp. kurstaki and ssp. tenebrionis (de Maagd et al. 2003). These Bt genes control a broad spectrum of lepidopteran and coleopteran insects, respectively. The genes have been approved for use in major row crops (feed corn and cotton) and some horticultural crops (sweet corn and potato). Potato and sweet corn varieties engineered for resistance to Colorado potato beetle and corn earworm, respectively, were in commercial production for several years and were technically and agronomically successful, allowing significant reductions in insecticide use (Shelton et al. 2002). However, the transgenic potato varieties were withdrawn from the market after major processors and distributors chose not to purchase and market them. Bt sweet corn, while still available, is not widely grown for the same reason (Cornell Cooperative Extension 2003).

Herbicide tolerance. Several

herbicide-tolerance genes are registered for use. The most widely commercialized gene is a bacterial enzyme conferring tolerance to glyphosate, the active ingredient of Roundup herbicide.

Transgenes conferring tolerance to bromoxynil (Buctril), glufosinate (Liberty) and sulfonylurea (Glean) herbicides are also approved for use in a wide variety of crops. In addition, crops tolerant to imidizolinone (Clearfield) and sulfonylurea herbicides have been developed through nontransgenic methods based on natural or induced mutations. However, no horticultural crops engineered for herbicide resistance have been commercialized, although several have been developed and tested.
Virus resistance. The use of viral coat protein genes to confer resistance has been approved for several viruscrop combinations (table 1). The most commercially successful has been papayas engineered for resistance to the papaya ringspot virus. This product has revived the Hawaiian papaya industry, which was devastated by the virus in the 1990s (see sidebar, page 92). Small acreages of transgenic squash resistant to mosaic viruses are also grown. Virus-resistant potato varieties were formerly commercialized but are not currently being marketed. Newer technologies, such as RNA interference or RNA silencing (Waterhouse et al. 2001), offer promise for developing resistance to other damaging diseases, such as those caused by geminiviruses (Gilbertson et al. 1998).

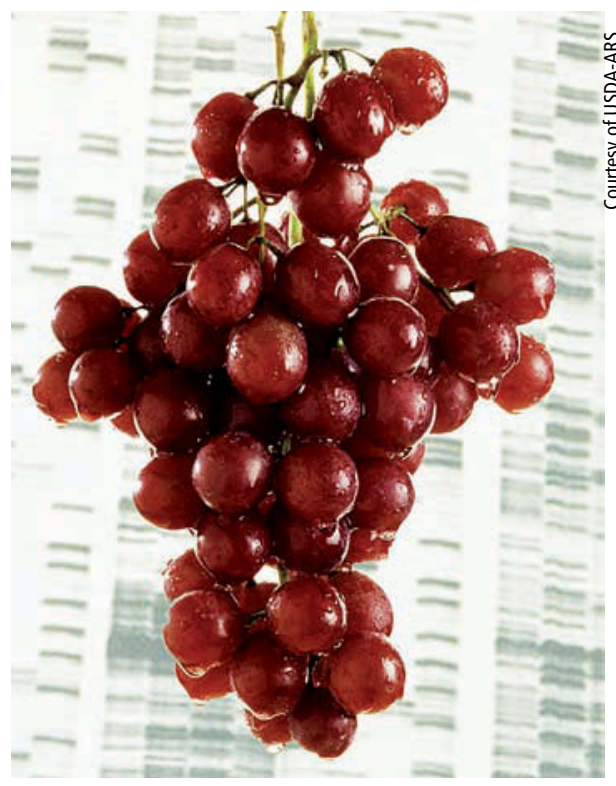

Left, scientists are investigating ways to prevent Pierce's disease in grapes by genetically engineering genes from a naturally resistant variety, Muscadinia rotundifolia, into susceptible varieties. In a peer-reviewed study, a parasitoid wasp that controls the diamondback moth, right, a canola pest, was not affected by Bt canola. ter taste. This product, first marketed in 1994, was a success with consumers but failed economically for a variety of reasons (Martineau 2001). This same gene was also used in a tomato variety processed for paste and marketed by Zeneca in the United Kingdom. The trait reduced processing costs and consumers accepted the clearly labeled product, until the European uproar over biotech foods forced it off the supermarket shelves.

U.S. regulatory agencies also approved several other delayed-ripening tomato varieties based on strategies targeted to block the ethylene biosynthetic pathway (ACC deaminase and antisense/ cosuppressed ACC synthase) that is essential for ripening. None of these products is currently marketed, despite their technical feasibility and potential consumer benefits. Rather, they were preempted by a nonbiotech approach utilizing the naturally occurring rin mutant of tomato that delays fruit ripening. Heterozygous plants produce fruits that ripen at a significantly slower rate than normal fruits. A nontransgenic approach achieved essentially the same objective, and aggressive breeding and marketing of the long-shelf-life rin hy-
Flavr Savr tomato. Transgenic horticultural crops providing direct benefits to the consumer have also been developed. Calgene's Flavr Savr tomato silenced the gene encoding polygalacturonase, an enzyme implicated in fruit softening. The expectation was that the tomato would soften and spoil more slowly and could be picked at a later stage of maturity. This later harvest, in principle, would permit greater development of flavor compounds and bet-

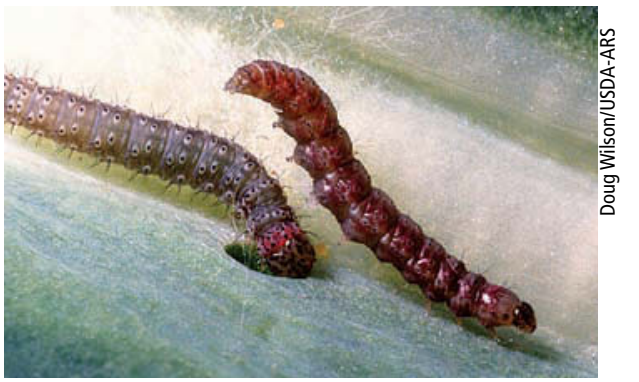


brid tomatoes made the transgenic approach redundant.

Lengthening postharvest time.

Similarly, virtually all bananas marketed in the United States are naturally deficient in their ability to initiate ethylene synthesis, allowing them to be shipped green and ripened by exposure to ethylene gas prior to sale. However, where natural mutants are not available, the general approach of manipulating ethylene synthesis has great potential for application in other climacteric fruits (whose ripening is mediated by ethylene), particularly tropical fruits with short postharvest lives such as mango, papaya and banana. A higher quality fruit bringing tangible value to the consumer could improve the market acceptance of biotech crops.

Despite their early introduction and initial market success, and in contrast to what many consumers may believe, the only biotech horticultural commodities currently marketed in the United States are Hawaiian papayas, a small amount of squash and sweet corn, and a few carnation varieties. The commonly cited estimate that as much as $70 \%$ of food products in U.S. supermarkets contain ingredients from GE crops is not attributable to fruits and vegetables, but rather to the widespread use of corn, canola and soybean oil, soybean protein, corn starch and related products in virtually all processed foods.

\section{Opportunities for biotechnology}

As global acreage of biotech agronomic crops sustains its eighth consecutive year of double-digit growth rates (increasing 15\% from 2002 to 2003) (James 2003), it is paradoxical that the trend in horticultural crops is exactly the opposite, particularly as many of the approved genes fit naturally with the needs of horticultural crops. Fear of consumer rejection on the part of both producers and marketers of horticultural products is a major impediment to wider utilization of biotechnology, even though many consumer polls do not find a majority negative opinion about it (see page 99). Many food companies are unwilling to risk the consequences of alienating even a small fraction of their potential market (Gillis 2000). Clearly, growers, distributors and consumers must all see biotech crops as in their best interests for commercialization to be successful. Products offering compelling value could alter the economic forces influencing producer choices and could create consumer demand to pull such products through the marketplace.

Loss of pesticides. One factor that may significantly alter grower economics is the loss of currently registered pesticides due to environmental and health concerns. For example, methyl bromide is scheduled to be withdrawn from use in the United States in 2005 because it contributes to depletion of the ozone layer. Methyl bromide is widely used in horticultural crops to control soilborne diseases and weeds and to fumigate harvested crops to eliminate insects. The majority of this use is in horticultural crops (primarily strawberries, tomatoes, peppers, ornamentals and nurseries, and tree crops) with California and Florida together accounting for $80 \%$ of the 35 million pounds applied each year for preplant fumigation (Economic Research Service 2000). Many genes are available that potentially could be used to enable alternative weed-control strategies.

Horticultural crops are also limited in the numbers of herbicides registered for use. Loss of registration for a few key chemicals could markedly limit grower options, making crop resistance to broad-spectrum herbicides more critical. Resistance to fungal and bacterial diseases would also be desirable, as in some areas extensive use of pesticides is currently undertaken for their control. As for herbicides, it is also difficult to maintain registrations for minor crops grown on smaller acreages, which are primarily horticultural. Biotech strategies are being developed that could provide broader spectrum disease control and reduced dependence upon chemical pesticides (Lincoln et al. 2002). Resistance to viral diseases would be valuable in many horticultural crops, as there are few other options for control, and methods for engineering virus resistance are well established.

Tree fruit, nuts and grapes. Research is well under-way to build a robust platform of technologies to utilize genomics in the discovery of useful traits for trees (Dandekar et al. 2002). Transformation technology has been developed and trait evaluation is under way on apple, almond, peach, citrus, walnut, pear, plum, grapevine and persimmon. Good progress has been made in developing resistance to codling moth and fireblight in apple, plum pox virus in plum/ Prunus, crown gall and codling moth in walnut, citrus tristeza virus (CTV) in citrus and Pierce's disease in grapevine.

Engineering of resistance to codling moth in apple to reduce the use of chemical pesticides has advanced to the point of commercial interest in product development. Work is also under way to develop productivity and quality traits such as modified sugar metabolism and ripening in apple and regulation of selfincompatibility in almond and other Prunus species. Some deployment strategies for transgenic trees are also being developed, such as the use of transgenic trees as "trap crops" to control insects in conventional orchards and the use of transgenic rootstocks to control diseases and pests in nontransgenic scion variet- 


\title{
Virus-resistant transgenic papaya helps save Hawaiian industry
}

\author{
Dennis Gonsalves
}

\begin{abstract}
$\mathrm{T}_{\mathrm{s}}$ he pivotal year in the history of Hawaii's papaya industry was 1992. In May 1992, papaya ringspot virus (PRSV) was discovered in Puna on Hawaii Island, where 95\% of Hawaii's papaya was being grown. Just one month earlier, a small field trial to test the resistance of a transgenic papaya line had been started on Oahu Island, where papaya production had previously been devastated by PRSV. The timely commercialization of PRSVresistant transgenic papaya trees has revived Hawaii's papaya industry and provides an example of the challenges and opportunities for horticultural biotechnology.

In 1945, D.D. Jensen made the first report in Hawaii of PRSV, a potyvirus that is transmitted nonpersistently by aphids (Gonsalves 1998). PRSV was first discovered on Oahu and caused such severe damage that the papaya industry was relocated to Puna in the late 1950s and early 1960s. The papaya industry expanded and prospered in
\end{abstract}

The experience in Hawaii shows that transgenic virus resistance is an excellent approach for controlling viral diseases in horticultural crops.

Puna, primarily because PRSV was absent. However, by the 1970s PRSV was found only about 19 miles away in Hilo, and the Hawaii Department of Agriculture (HDOA) took rouging (the removal of infected trees) and quarantine actions to prevent its spread to Puna. In 1986, efforts were initiated to develop a virus-resistant transgenic papaya by transforming commercial lines of Hawaiian papaya with the coat protein gene of PRSV from Hawaii.

By 1991, the team of Maureen Fitch, Jerry Slightom, Richard Manshardt and Dennis Gonsalves identified a transgenic line (55-1) that showed resistance under greenhouse inoculations. These plants were micropa- gated and established in a field trial in Waimanalo on Oahu in April 1992. By December 1992, it was evident that line 55-1 was resistant under field conditions. From the 1992 field trial, two cultivars were developed and designated 'SunUp' and 'Rainbow'. 'Sun$\mathrm{Up}^{\prime}$ is homozygous for the coat protein gene while 'Rainbow' is an Fl hybrid of 'SunUp' and the nontransgenic 'Kapoho'. Unfortunately, by Oc-

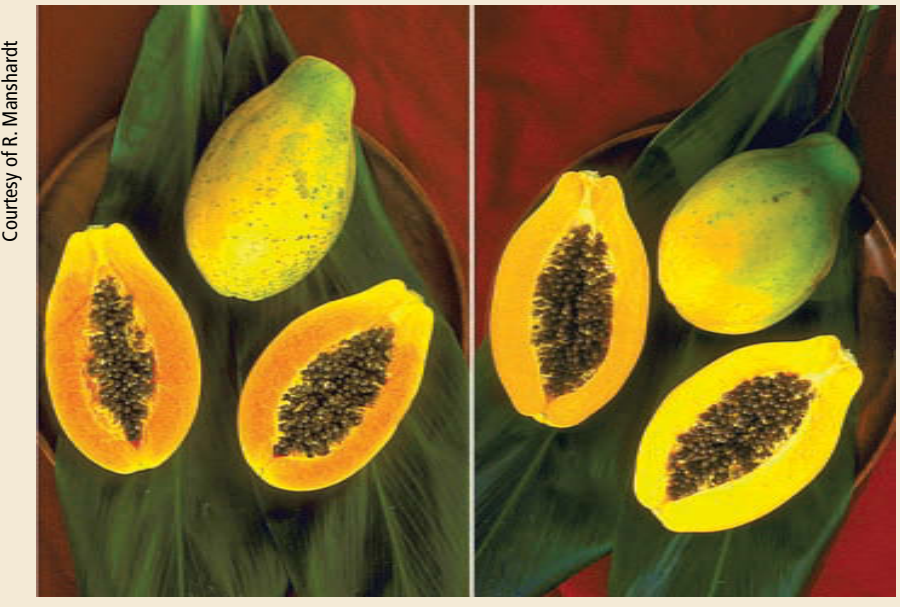

Two varieties of papaya resistant to papaya ringspot virus have been developed using biotechnology: SunUp, left, and Rainbow, right. They have performed well for Hawaiian growers, even under prolonged and heavy disease pressure.

tober 1994, PRSV had spread throughout much of Puna, causing HDOA to abandon rouging efforts to slow the spread of PRSV. The race was on to move the transgenic papaya line to commercialization. A 1995 field trial in Puna conclusively showed that 'SunUp' and 'Rainbow' were resistant under prolonged and heavy disease pressure.

The U.S. Department of Agriculture's Animal Plant Health Inspection Service (APHIS) deregulated transgenic line 55-1 in November 1996, and the U.S. Environmental Protection Agency deregulated it in August 1997. The consultation process with the U.S. Food and Drug Administration was completed in September 1997. Licenses to commercialize the transgenic papaya were obtained by the Papaya Administrative Committee in Hawaii by April 1998. A celebration was held to mark the debut of the transgenic papaya on May 1, 6 years after PRSV was discovered in Puna and after the first field trial of line 55-1 was initiated. The transgenic fruit is currently sold throughout the United States.

In 1992, Puna produced 53 million pounds of papaya, but by 1998 produc- tion had dropped to only 26 million pounds as PRSV spread throughout the region. Since then, the transgenic varieties have enabled farmers to reclaim infected areas and in 2001, Puna produced 40 million pounds of papaya. The resistance has held up remarkably well and remains stable after 5 years of extensive plantings.

Hawaii also exports papaya to Canada and Japan. The transgenic papaya was recently deregulated in Canada, which is a relatively small market for Hawaii. The main challenge is deregulation of transgenic papaya in Japan, where Hawaii sells about $30 \%$ of its papaya. Presently, nontransgenic papaya must also be produced in Hawaii to satisfy the Japanese market, but this is increasingly difficult due to the disease pressure. Exporters face added expenses to guard against the accidental shipment of transgenic papaya to Japan. In December 2000, Japan's Ministry of Agriculture, Forestry and Fisheries approved line 55-1, and the Ministry of Health, Labor and Welfare is reviewing a recently submitted petition for deregulation. Anticipated approval of transgenic papaya in Japan will allow Hawai- 


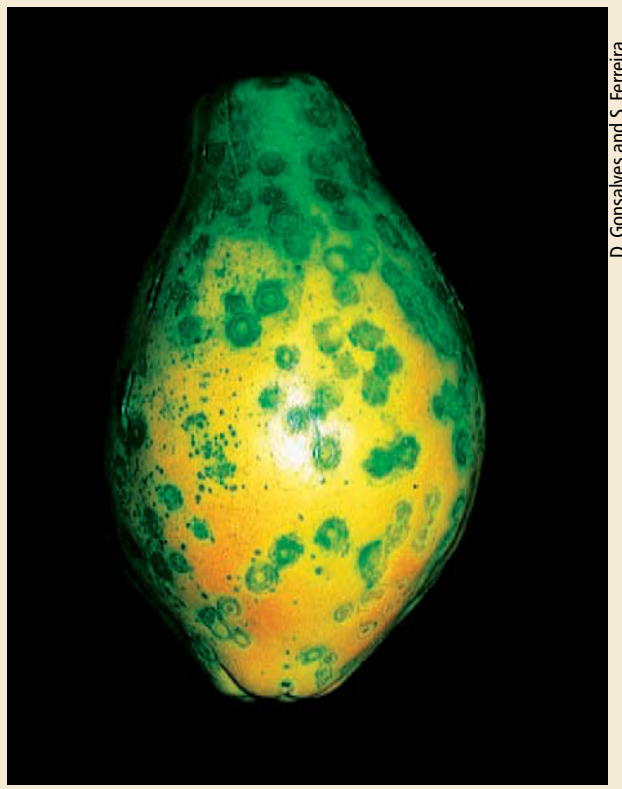

Papaya ringspot virus causes small, darkened rings on the surface of fruit, as well as foliar damage.

ian growers to expand their transgenic papaya markets and will eliminate excessive costs associated with segregating trans-genic and nontransgenic fruits.

The experience in Hawaii shows that transgenic virus resistance is an excellent approach for controlling viral diseases in horticultural crops. This industry was fortunate to have a potential product already under development when PRSV was discovered in the main growing area of Puna. There are many reports that virus-resistant transgenic plants are being developed in diverse crops, but few have been commercialized. The papaya story shows that this approach can provide a stable and safe option for virus protection that can be essential for the success of specific horticultural crops.

D. Gonsalves is Director, Pacific Basin Agricultural Research Center, USDAARS, Hilo, Hawaii.

\section{Reference}

Gonsalves D. 1998. Control of papaya ringspot virus in papaya: A case study. Annu Rev Phytopathol 36:415-37.

Simply the diversity of crops utilized in horticulture slows the adoption of new technologies. For example, as many as 60 distinct cultivars of iceberg lettuce alone may be grown throughout the year.

ies (see sidebar, page 96). The latter approach avoids the task of transforming many varieties of a particular tree crop and in the future may be used to regulate quality and productivity traits.

Nutrients, consumer qualities. Although more difficult technically and therefore not close to market, there are many potential opportunities for enhancing the nutritional value or consumer appeal of horticultural products through biotechnology. In addition to modification of ripening, projects to increase the content of vitamins, minerals or nutraceuticals in horticultural products are in progress (Grusak and Della Penna 1999). The development of Golden Rice with enhanced betacarotene (pro-vitamin A) in the grain (Ye et al. 2000) demonstrated the potential for biotechnology to increase nutritional value. Whether such products will have sufficient consumer appeal in fully developed markets to drive their commercialization remains to be seen.

\section{Floriculture, ornamental plants}

Since floricultural and ornamental plants are grown for aesthetic or other nonedible purposes, there may be less potential for public concern about GE varieties than there has been with biotech food crops.

Flower color. Several ornamental plants, including carnation, rose and gerbera, have been engineered for modified flower color. Research has focused on the manipulation of either anthocyanins (red and blue colors) or carotenoids (yellow and orange colors), with the intent of creating a wider range of flower colors than occurs naturally, as well as to produce natural dyes for industrial purposes (Lu et al. 2003). Florigene is selling Transgenic Moon

series carnations engineered for dark violet-purple color around the world. The varieties are developed in Australia and flowers are produced primarily in South America for marketing in the United States and Japan.

Floral scent. Putting the scent back into flowers that have "lost" this trait over years of traditional hybridization and selection, or creating new fragrances in plants, has considerable potential and appeal. Research on genes controlling the different biochemical pathways for various floral fragrances is being conducted on wild plants and on crops such as snapdragon, petunia and rose (Vainstein et al. 2001).

Plant size. Currently, growthregulating chemicals are applied to ornamental plants to inhibit gibberellic acid (GA) synthesis and reduce plant height during crop production. Many newly introduced ornamental species are receiving particular attention via conventional breeding for dwarf plants because their natural habits do not fit into marketing systems requiring compact plants. The manipulation of GA metabolism via biotechnology has the potential to produce ornamental and flowering plants with reduced-height phenotypes (Clark et al. 2003). The development of lawn grasses that require significantly less frequent mowing is another obvious application. Early experiments suggest that expression of genes controlling height can be applied to many plant species.

Leaf life. Engineering of plants to delay leaf senescence (yellowing) is also being pursued in ornamental crops. For years, ornamental breeders have selected new cultivars of plants with more attractive "stay green" phenotypes. Cytokinins are plant hormones well known to delay the loss of chlorophyll in leaves; using biotechnology, targeted expression of genes involved in cytokinin synthesis is now possible. When a gene promoting cytokinin biosynthesis is inserted into plants in conjunction with a regulator (promoter) that turns the gene on only when the leaf starts to senesce, leaf life is extended in transgenic plants exposed to drought, nutrition and pathogen stress (Gan and Amasino 1995; Clark et al. 2004).

Ethylene sensitivity. As in fruit ripening, manipulation of ethylene synthesis or sensitivity has applications in the ornamental plant industry. Ethylene accelerates floral and foliar senescence, and chemical methods have been developed to miti- 


\section{Biotechnology expands pest-management options for horticulture}

\section{Leonard Gianessi}

$\mathrm{F}$ der constant pressure from pests such as weeds, viruses, fungi, bacteria, insects and nematodes. If not controlled, many of these pests substantially lower yields. Successful agricultural production has depended on the use of pesticides for 100 years, and, yet, losses still occur due to certain pests that are poorly controlled. Some crops incur high costs for hiring laborers to hoe weeds because there are no effective herbicides. In addition, new pests routinely arrive for which effective controls have not yet been developed.

Agricultural researchers continuously seek out new methods to control pests, including biological agents, new chemicals and plant resistance through classical breeding. Biotechnology also offers a solution in some situations where traditional methods are ineffective or costly. Numerous researchers around the world are investigating biotechnological solutions to pest problems of horticultural crops. In 2002, the National Center for Food and Agricultural Policy released a study of current and potential biotechnological approaches to pest management in a wide array of crops (Gianessi et al. 2002).

Current plantings. The study identified three varieties of transgenic fruits and vegetables that are currently planted on small acreages in the United States: virus-resistant squash is grown on 5,000 acres in the Southeast, to prevent late-season losses to mosaic viruses; virusresistant papaya is widely planted in Hawaii (2,000 acres)(see sidebar, page 92); and insect-resistant sweet corn is planted on a small number of acres and has reduced use of insecticide sprays.

Withdrawn varieties. Two transgenic horticultural varieties were available for a short time in the United States but were withdrawn due to marketing concerns. Insect- and virus-resistant New Leaf potatoes were planted on $4 \%$ of the nation's acreage

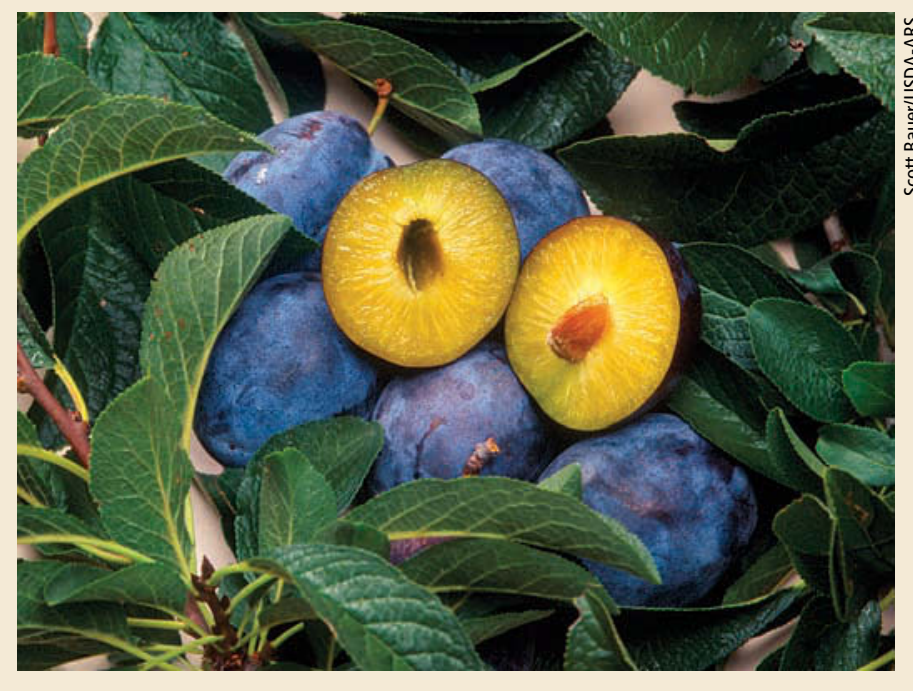

Plums resistant to the plum pox virus have been developed by scientists with the U.S. Department of Agriculture but are not yet available to growers. in 1999 and were credited with reducing insecticide use. If the transgenic varieties had not been withdrawn due to processor resistance they could have been planted extensively in the Northwest, reducing insecticide use by 1.4 million pounds.

In 1999, the U.S. Environmental Protection Agency (EPA) granted Wisconsin sweet-corn growers emergency permission to spray herbicide-tolerant varieties (see sidebar, page 110). The transgenic varieties were not widely planted due to marketing concerns and growers have not reapplied for the use despite continued production losses.

Crops currently being tested. $\mathrm{Nu}-$ merous fruits and vegetables have been transformed through genetic engineering and are being tested for their potential role in improving pest management. For example, University of Florida researchers are testing virus-resistant tomatoes as a substitute for the extensive insecticide spraying currently utilized to control insects vectoring geminiviruses. In California, herbicide-tolerant processing tomatoes have been tested and have the potential to reduce grower costs by
$\$ 30$ million and replace the use of 4.2 million pounds of fumigants.

UC researchers have tested herbicidetolerant lettuce that could reduce herbicide use by 140,000 pounds a year. Herbicide-tolerant strawberries could save Eastern growers several hundred dollars per acre in weed-control costs. Nematode-resistant pineapple is being developed at the University of Hawaii to replace 1.4 million pounds of fumigants. Insect-resistant broccoli developed at Cornell University could improve yields in years of heavy insect pressure. Virus-resistant raspberries developed by U.S. Department of Agriculture (USDA) researchers in the Northwest could help combat bushy dwarf virus, which is present in $80 \%$ of Northwest plantings. And transgenic apples resistant to fire blight bacteria have been developed and tested at Cornell University; the transgenic varieties would replace the use of antibiotics, which are used to kill the bacteria on $25 \%$ of U.S. apple acreage.

Emerging pests. Several research programs are focused on biotechnological approaches to control emerging pest problems. Plum pox virus was detected in the United States for the first time in Pennsylvania, where efforts are under way to eradicate it by destroying infected trees. USDA researchers have developed a virus- 
resistant plum that is being tested in Europe. If plum pox virus reaches California, the trans-genic plum could help prevent losses to the state's multibillion dollar stone-fruit industry.

Pierce's disease threatens California vineyards, and insecticide spraying has occurred to control the disease carrier, the glassy-winged sharpshooter. A researcher at the University of Florida (a state where Pierce's disease has been a problem for 80 years) has transformed grape tissue by inserting an antibacterial protein from another species into the grape genome. As a result, the transformed grape plant can destroy the bacteria without the need for insecticide sprays targeting the carrier.

Tristeza virus has killed 45 million citrus trees in Latin America and threatens the Texas citrus industry. Researchers at Texas A\&M University have developed and are field testing virus-resistant trees.

Bacterial canker is present in Florida citrus orchards, and the state is trying to eradicate the disease by destroying infected trees, including millions of orchard and backyard citrus trees. A University of Florida researcher has developed and is testing a canker-resistant citrus tree.

\section{Gianessi is Director, Crop Protection Research Institute, CropLife Founda- tion, Washington, D.C. The foundation is an independent, nonprofit research organization.}

\section{Reference}

Gianessi LP, Silvers CS, Sankula S, Carpenter JE. 2002. Plant Biotechnology: Current and Potential Impact for Improving Pest Management in U.S. Agriculture; An Analysis of 40 Case Studies. National Center for Food and Agricultural Policy, Washington, DC. www.ncfap.org/40CaseStudies.htm.

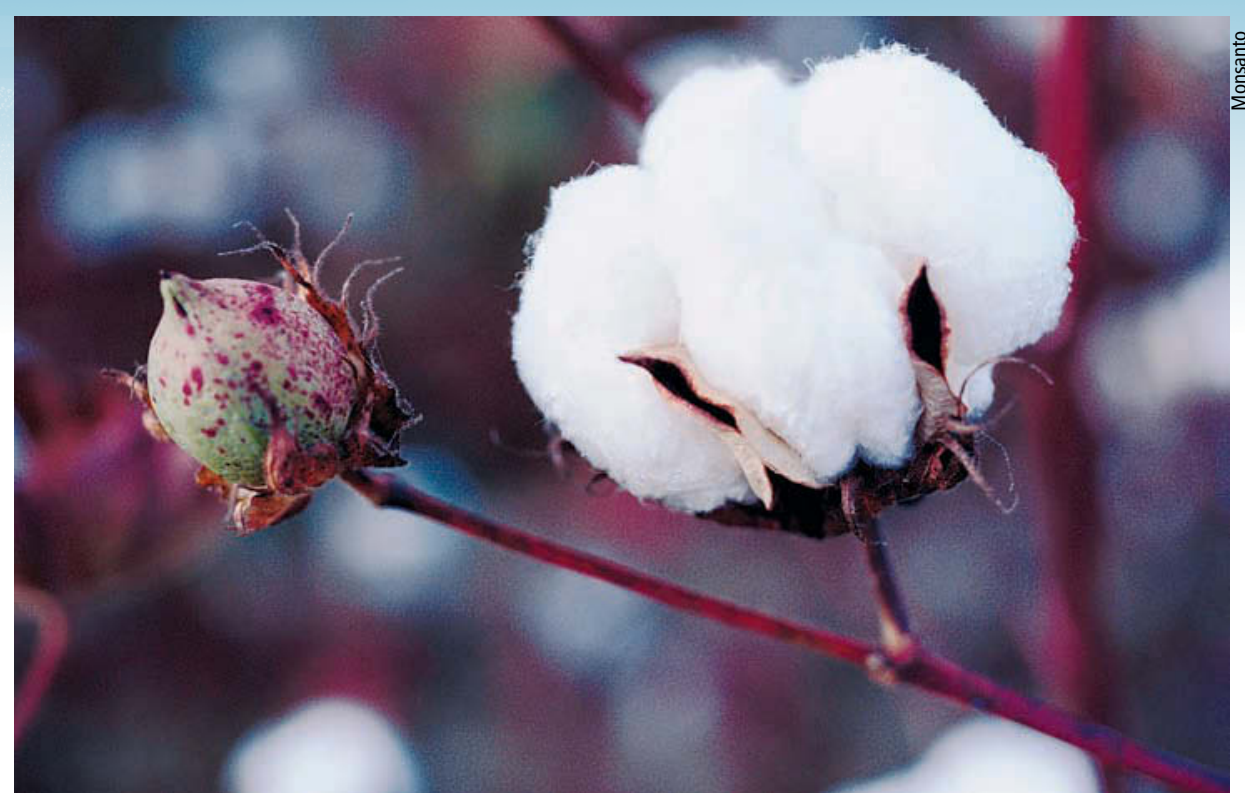

Cotton has been genetically engineered to express a protein from a naturally occurring bacterium, Bacillus thuringiensis, which is toxic to insect pests such as bollworm and budworm. This cotton is widely planted in California and elsewhere in the United States.

gate its effects (Sisler and Serek 2003). Ethylene sensitivity can be reduced in floriculture crops through applications of the ethylene antagonist silver thiosulfate (STS), but unfavorable environmental aspects such as metal contamination of groundwater restrict its commercial use. Another compound, 1-methylcyclopropene, also blocks the ethylene receptor protein and makes plant tissues insensitive to ethylene, delaying ripening or senescence. Although this compound is effective in many crops, its action decreases with time after treatment as the tissues synthesize new ethylene receptor proteins during postharvest transit. By expressing a mutant form of the ethylene receptor protein or by blocking expression of components of the ethylenesignaling pathway, petunia plants with longer lasting floral displays have been produced (Wilkinson et al. 1997). Unfortunately, negative side effects, such as higher susceptibility to fungal pathogens and decreased rooting of vegetative cuttings, have limited the commercial use of these technologies. The key to effective manipulation of ethylene sensitivity will be the use of promoters limiting transgene expression to the target tissue, leading ultimately to plants that have longer lasting flowers with no negative side effects.

\section{Hurdles to commercialization}

The lag in commercialization of transgenic horticultural crops clearly is not due to a lack of useful genes or valuable applications. However, several fundamental issues inherent to horticultural crops create significant hurdles (see sidebar, page 84).

Biological diversity. Simply the diversity of crops utilized in horticulture slows the adoption of new technologies. For any given crop, there may be several different species and dozens of cultivars that are currently marketed, and the turnover of new cultivars from year to year is tremendous. For example, as many as 60 distinct cultivars of iceberg lettuce alone may be grown throughout the year as production locations shift seasonally. Add to this the dozens of additional varieties for romaine, leafy, red and other specialty types, and it is evident that introducing a new biotech trait for lettuce requires developing not just one but many new varieties. In perennials such as trees and vines, on the other hand, the choice of a variety is a longterm commitment, making growers cautious in selecting novel varieties.

Market acceptance. Currently, the largest impediment to adoption of at least some biotech horticultural products is the lack of market acceptance. Biotech products having documented agronomic, economic and environmental advantages have been removed from the market due to the concerns of processors and distributors about potential consumer rejection.

Intellectual property. Large corporations focused on the major agronomic crops own the majority of patents on 


\section{Transgenic trap crops and rootstocks show potential}

\author{
John Driver \\ Javier Castillón \\ Abhaya Dandekar
}

$\mathrm{B}$ iotechnology may offer unique opportunities for pest control in perennial tree and vine crops (Dandekar et al. 2002). Trap crops - plants that an insect pest prefers to the commercial crop - have been tested in a number of agricultural settings, but in most cases have not achieved control levels high enough to completely replace chemical pesticides. Insects are attracted to the trap plant, but they multiply there and can spread to the adjacent crop. A variant on this concept is to incorporate expression of the Bacillus thuringiensis (Bt) insecticidal protein into the trap plant. When the insect feeds on the transgenic trap plant, it dies and the insect population is reduced, thereby protecting the nearby commercial crop.

Dry Creek Laboratories of Hughson, Calif., demonstrated this concept with codling moth (Cydia pomonella), a major pest of apples, pears, walnuts and other fruits. The female moth lays eggs on the leaves or fruit, which then hatch into larvae that burrow into the fruits, making them unmarketable. Pesticide sprays and pheromone dis-

\section{When the insect feeds on the population is reduced, thereby pro}

ruption are generally used to control this pest. However, the female moth prefers to lay its eggs on apple trees. Under license from Monsanto, Dry Creek Laboratories developed apple trees capable of expressing a Bt protein that was toxic to the codling moth larvae, with the intention of using these plants as trap crops in and adjacent to walnut orchards.

A 90-acre field trial was established in 1997, and in the 4 subsequent years worm damage to the walnuts was almost completely controlled without pesticide applications, equivalent to that in the plots sprayed three times per season with pesticides. While walnuts have also been transformed to ex-
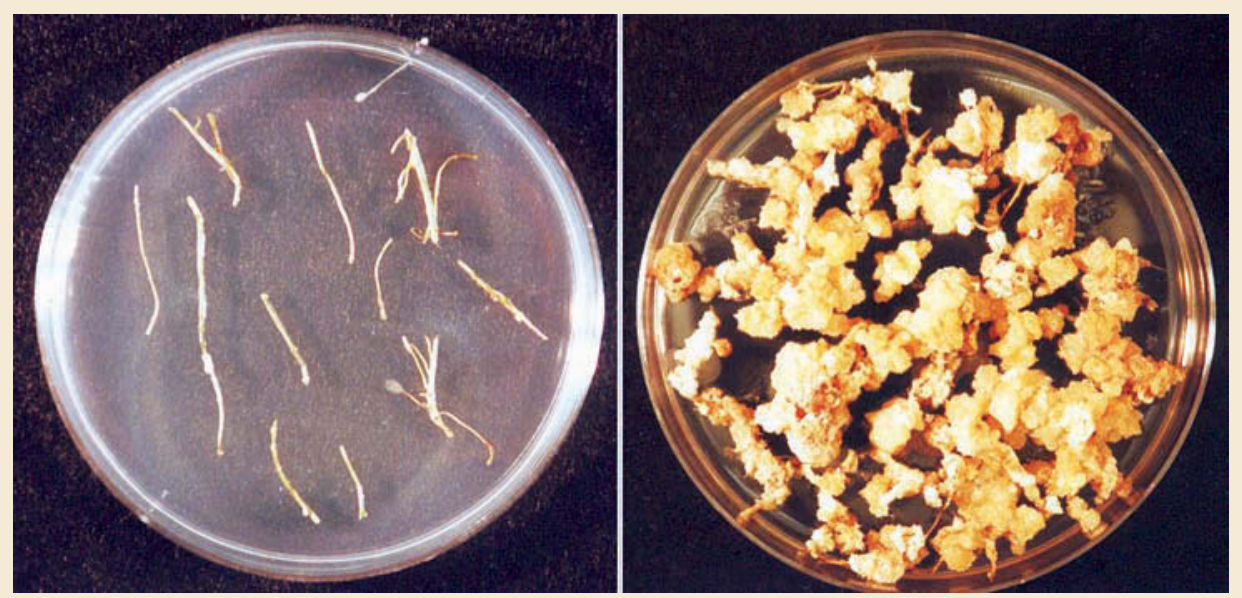

Left, apple roots engineered to silence bacterial genes are resistant to crown gall formation. Right, control (nontransgenic) roots infected with the same bacterial strain show extensive gall proliferation.

press the Bt protein directly (Dandekar et al. 2002), an attractive feature of this scheme is that the walnuts themselves are not transgenic and the method could be used to protect existing orchards by interplanting the Bt-expressing apple or crabapple trees. Broader application of this approach could result in more effective trap crops for a number of annual and perennial crops. Unfortunately, Dry Creek Laboratories is unable to move forward at this time with commercialization of the Bt apple plants due to the costs associated with bacterium result in the formation of a gall, an unorganized mass of plant cells that results from overproduction of two plant hormones. The bacterium has the natural ability to transfer some of its genes into the host plant's genome following infection. The transferred genes code for three specific enzymes. When the plant expresses these genes, the enzymes synthesize the two hormones that induce the plant to form the tumor, or gall, on which the bacteria live. Eventually, the galls can girdle the stems and reduce the vigor of the tree or vine. A biotechnology

the regulatory process required for biotech crops (see page 106).

Another opportunity for biotechnology in perennial crops that are normally grafted is to engineer only the rootstock for desirable traits. Commercial tree cultivars grafted onto transgenic rootstocks could benefit from increased rootstock productivity or disease resistance while producing nontransgenic pollen and fruit. For example, such applications in grapes could offer new solutions to Pierce's disease or Phylloxera by grafting traditional varieties onto resistant transgenic rootstocks. The feasibility of this approach was recently demonstrated for resistance to crown gall disease (Agrobacterium tumefaciens). Infections by the tool called "gene silencing" has been used to generate resistance

d the insect cial crop. to crown gall. This method involves transforming plants with DNA that, when expressed, produces signals that block the expression of any genes with the same sequence as the inserted DNA. Plants transformed with these interfering versions of the three enzyme genes would be primed to block the function of the corresponding bacterial genes in infected plants. This would prevent the formation of the damaging galls without even needing to kill the bacterium itself. The feasibility of this approach was demonstrated in tomato and Arabidopsis plants (Esconut (see photo; Escobar et al. 2002) and apple (see photo; J. Driver et al., unbar et al. 2001). Furthermore, both wal- 


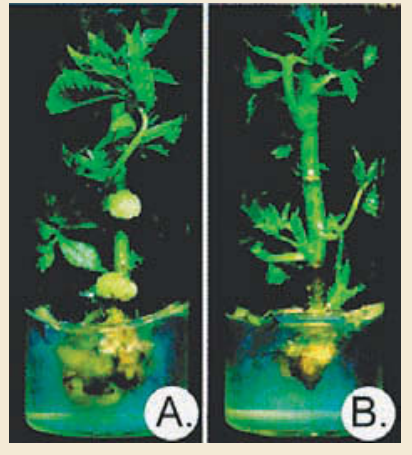

Crown gall formation was suppressed in walnut plants engineered to turn off specific bacterial genes. (A) The control shoot exhibits a large, undifferentiated tumor at 5 weeks after inoculation with a virulent A. tumefaciens strain, while (B) a shoot engineered for resistance exhibits no tumor. Source: Escobar et al. 2002.

published results) plants resistant to crown gall have been produced. As most crown gall infections occur in the rootstock, nontransgenic scions grafted on resistant transgenic rootstocks would be protected from the disease. Rootstock engineering holds great promise for the improvement of tree and vine crops by preserving the horticultural characteristics of existing varieties used as scions while incorporating beneficial traits into the rootstocks.

\section{J. Driver is former President and J. Castillón is Director of Research, Dry Creek Laboratories, Hughson, Calif.; and A. Dandekar is Professor, Depart- ment of Pomology, UC Davis.}

\section{References}

Dandekar AM, Fisk HJ, McGranahan $\mathrm{GH}$, et al. 2002. Different genes for different folks in tree crops: What works and what does not. Hort Sci 37:281-6.

Escobar MA, Civerolo EL, Summerfelt KR, Dandekar AM. 2001. RNAi-mediated oncogene silencing confers resistance to crown gall tumorigenesis. Proc Natl Acad Sci USA 98:13437-42.

Escobar MA, Leslie CA, McGranahan $\mathrm{GH}$, Dandekar AM. 2002. Silencing crown gall disease in walnut (Juglans regia L.). Plant Sci 163:591-7. the genes and enabling technologies (such as transformation protocols and promoters) required for genetically engineering plants. They are generally not interested in the smaller horticultural markets, and may not want to license their technologies, depending on the impact it could have on their other approved crops (see page 120).

Post-commercialization. Postcommercialization stewardship is also an increasingly important consideration to technology owners in deciding whether to license their intellectual property. In Bt crops, for example, insect-resistance management programs must be developed and monitored after commercialization. Identity preservation programs and segregation of products in the distribution channels may be required when marketing in locations where they are not approved. Herbicide applications to diverse horticultural crops have the potential to increase the Average Daily Intake (ADI) over the maximum permitted level for the pesticide active ingredient. (ADI is the total residues of a pesticide that a consumer can be exposed to, considering all sources; the government sets limits for each pesticide.) An agrochemical company will not approve the use of its herbicide-resistance trait in a small acreage crop if it endangers the registration of that herbicide for millions of acres of field crops.

Regulatory requirements. Extensive safety testing is required for regulatory approval (deregulation) of biotech crops beyond what is required for varieties bred using traditional methods (see page 106). If the trait has already been approved in other crops, the costs are lower as prior data can be used to support an application. However, for novel traits likely to be of interest for horticultural crops, the costs could be millions of dollars. For example, by some estimates it will cost $\$ 20$ million to achieve deregulation of Golden Rice for humanitarian purposes in six developing countries (I. Potrykus, UC Davis seminar, Jan. 22, 2003). Since each transgenic event (each insertion of a gene in a genome) must be separately tested and approved, it is not feasible to transform multiple varieties with a given trait to amortize the research and technology investment across a given crop. Instead, a single insertion event is approved for commercialization and then must be transferred via standard backcrossing to other varieties. This is highly inefficient and often makes it difficult to regain the unique properties of all the diverse varieties. Public-private partnerships are one way to reduce the costs of commercialization (see page 116). The IR-4

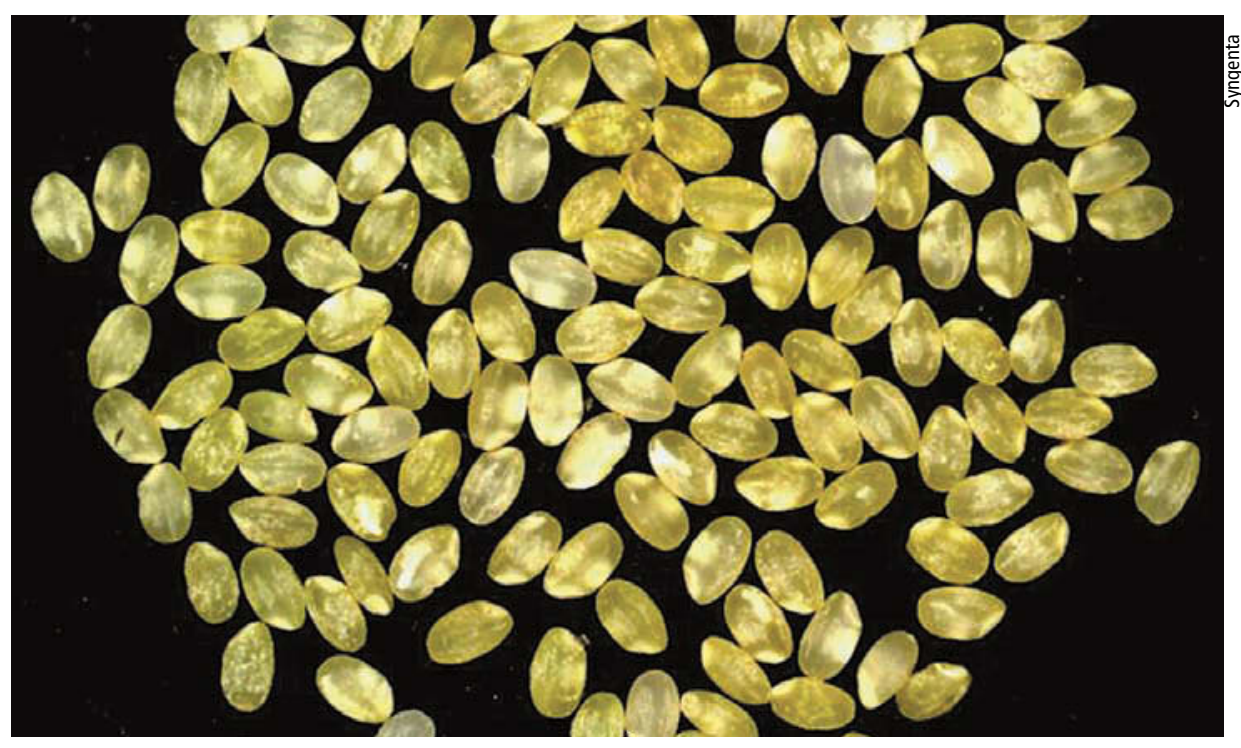

"Golden Rice" has been genetically engineered to produce beta-carotene, the precursor to vitamin A. However, for a variety of reasons it is not yet available to farmers in developing countries, where vitamin A deficiencies are common. 
program could also assist with chemical residue testing and with other aspects of meeting the regulatory requirements for release of transgenic horticultural crops (see sidebar, page 110).

\section{Compelling benefits key}

The commercial applications of biotechnology to horticultural crops lag far behind those of agronomic crops. In some respects this is to be expected, since the majority of research and investment has been directed to commodities with the greatest commercial value. For consumer and quality traits, however, many of the most interesting applications will be in horticultural crops. Intellectual-property issues must be resolved and regulatory costs reduced before significant progress can be made toward commercialization of transgenic products. However, the major impediment to horticultural biotechnology is the reluctance of the market to accept and actively promote these products. The development of products having compelling benefits for producers, marketers and consumers may be required to overcome this situation.

\section{Clark is Associate Professor, Environ-} mental Horticulture Department, and $H$. Klee is Eminent Scholar, Horticultural Sciences Department, University of Florida, Gainesville; and A. Dandekar is Professor, Department of Pomology, UC Davis.

\section{References}

Clark DG, Dervinis C, Barrett JE, Klee HJ. 2004. Drought-induced leaf senescence and horticultural performance of transgenic psag12-IPT petunias. J Amer Soc Hort Sci 129:93-9.

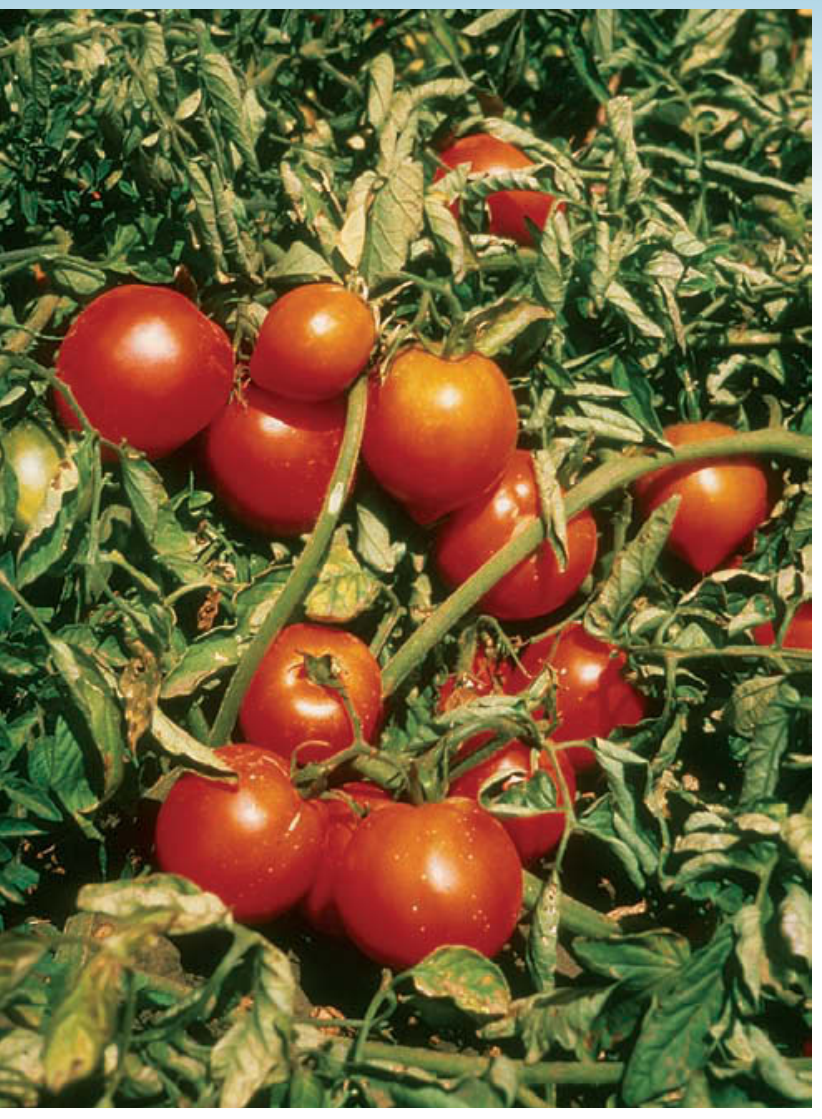

The first transgenic crop to receive U.S. government approval was a tomato engineered to soften more slowly than conventional tomatoes, allowing it to be picked later for improved flavor and taste. Bioengineered horticultural crops with clear benefits to consumers may be needed to overcome market reluctance. Above, conventional tomatoes.

Clark DG, Loucas $\mathrm{H}$, Shibuya $\mathrm{K}$, et al. 2003. Biotechnology of floriculture crops scientific questions and real world answers. In: Vasil IK (ed.). Plant Biotechnology 2002 and Beyond. Dordrecht, Netherlands: Kluwer Academic. p 337-42.

Cornell Cooperative Extension. 2003. Am I eating GE potatoes? Genetically Engineered Organisms: Public Issues Education Project. www.geo-pie.cornell.edu//crops/ potato.html (accessed 3/16/04).

Dandekar AM, Fisk HJ, McGranahan GH, et al. 2002. Different genes for different folks in tree crops: What works and what does not. Hort Sci 37:281-6.

Dandekar AM, Gutterson N. 2000. Genetic engineering to improve quality, productivity and value of crops. Cal Ag 54(4):49-56.

de Maagd RA, Bravo A, Berry C, et al. 2003. Structure, diversity, and evolution of protein toxins from spore-forming entomopathogenic bacteria. Annu Rev Genet 37:409-33.

Economic Research Service. 2000. Economic Implications of the Methyl Bromide Phaseout. U.S. Department of Agriculture. Ag Info Bull No 756. www.ers.usda.gov/ publications/aib756/.

Gan SS, Amasino RM. 1995. Inhibition of leaf senescence by autoregulated production of cytokinin. Science 270:1986-8.
Gilbertson RL, Ullman DE, Salati $\mathrm{RS}$, et al. 1998. Insect-transmitted viruses threaten agriculture. $\mathrm{Cal} \mathrm{Ag}$ 52(2):23-8.

Gillis J. 2000. New seed planted in genetic flap. Washington Post. Feb 6:H1.

Grusak MA, Della Penna D. 1999. Improving the nutrient composition of plants to enhance human nutrition and health. Annu Rev Plant Physiol Plant Mol Biol 50:133-61.

[HASS] Hawaii Agricultural Statistics Service. 2001. Papaya Acreage Survey Results. www.nass.usda. gov/hi/prlsetoc.htm.

James C. 2003. Preview: Global Status of Commercialized Transgenic Crops: 2003. ISAAA Briefs No 30. Ithaca, NY. www.isaaa.org.

Lincoln JE, Richael C, Overduin $B$, et al. 2002. Expression of the antiapoptotic baculovirus p35 gene in tomato blocks programmed cell death and provides broad-spectrum resistance to disease. Proc Natl Acad Sci USA 99:15217-21.

Lu CY, Chandler SF, Mason JG, Brugliera F. 2003. Florigene flowers: From laboratory to market. In: Vasil IK (ed.). Plant Biotechnology 2002 and Beyond. Dordrecht, Netherlands: Kluwer Academic. $p$ 333-6. www.florigene.com.

Martineau B. 2001. First Fruit: The Creation of the Flavr Savr Tomato and the Birth of Biotech Foods. New York: McGrawHill. 224 p.

Shelton AM, Zhao J-Z, Roush RT. 2002. Economic, ecological, food safety, and social consequences of the deployment of $B t$ transgenic plants. Annu Rev Entomol 47:845-81.

Sisler EC, Serek M. 2003. Compounds interacting with the ethylene receptor in plants. Plant Biol 5:473-80.

Waterhouse PM, Wang M-B, Lough T. 2001. Gene silencing as an adaptive defence against viruses. Nature 411:834-42.

Wilkinson J, Lanahan M, Clark D, et al. 1997. A dominant mutant receptor from Arabidopsis confers ethylene insensitivity in heterologous plants. Nature Biotech 15:444-7.

Vainstein A, Lewinsohn E, Pichersky E, Weiss D. 2001. Floral fragrance. New inroads into an old commodity. Plant Physiol 127:1383-9.

Ye XD, Al-Babili S, Kloti A, et al. 2000 Engineering the provitamin A (beta-carotene) biosynthetic option into (carotenoidfree) rice endosperm. Science 287:303-5. 